\title{
Introducing teaching portfolio in Medical Colleges: Scope and Components
}

\author{
Shrivastava, S. R. ${ }^{1}$, Shrivastava, P. S. ${ }^{2}$
}

\begin{abstract}
The teachers working in a medical college set-up has to fulfill multiple roles, namely teaching, research, patient care, mentor as well as a learner. Teaching portfolio refers to set of materials which depict the teaching practice of a teacher, which in turn enriches the process of student learning and is being supported by evidence for the same. It is a dynamic document and represents information about teaching achievements, skills and strategies employed by teachers for facilitation of students' learning. The process of maintaining portfolio has to go hand-in-hand with the collection of evidence which infers about the quality of teaching. In conclusion, the practice of maintaining a teaching portfolio should be encouraged by all the medical colleges as this is bound to affect the professional growth of teachers, impact students' learning and also enhance the level of satisfaction while serving as a teacher in a medical college.
\end{abstract}

Keywords: Teacher, Portfolio, Medical college

\section{Introduction}

The teachers working in a medical college setup has to fulfill multiple roles, namely teaching, research, patient care, mentor as well as a learner. It is quite important to measure the effectiveness of the faculty members in discharging these roles, as it not only gives insights about the quality of teaching, but also provides us evidence about the professional growth, in terms of annual increment or promotion (Lamki \& Marchand, 2006, Sidhu, 2015). There can be multiple ways in which a

${ }^{1}$ Member of the Medical Education Unit and Institute Research Council, Department of Community Medicine, Shri Sathya Sai Medical College \& Research Institute, Sri Balaji Vidyapeeth - Deemed to be University, Ammapettai, Nellikuppam, Chengalpet District, Tamil Nadu, India

${ }^{2}$ Department of Community Medicine, Shri Sathya Sai Medical College \& Research Institute, Sri Balaji Vidyapeeth - Deemed to be University, Ammapettai, Nellikuppam, Chengalpet District, Tamil Nadu, India

Corresponding Author:

Dr. Saurabh RamBihariLal Shrivastava

Professor, Department of Community Medicine, Shri Sathya Sai Medical College and Research Institute, Sri Balaji Vidyapeeth (SBV) - Deemed to be University, Tiruporur - Guduvancherry Main Road, Ammapettai, Nellikuppam, Chengalpet District, Tamil Nadu - 603108, India

Email:drshrishri2008@gmail.com teaching effectiveness can be assessed, and one of them being maintenance of a teaching portfolio by the teachers.

\section{Teaching Portfolio}

Teaching portfolio refers to set of materials which depict the teaching practice of a teacher, which in turn enriches the process of student learning and is being supported by evidence for the same (Lamki \& Marchand, 2006, Sidhu, 2015). It is a dynamic document and represents information about teaching achievements, skills and strategies employed by teachers for facilitation of students' learning.

The practice of maintaining a teaching portfolio should be looked upon as a vital tool for stimulating the professional development of a teacher predominantly through self-directed learning and reflection of their teaching practices (Table 1). In the process of documentation of educational accomplishments, it is vital that a teacher should start the process well in advance and this has to be in alignment with the periodic updation of the curriculum vitae (Sidhu, 2015, Little-Wienert \& Mazzigotti, 2018).

DOI: http://doi.org/10.4038/seajme.v14i2.247

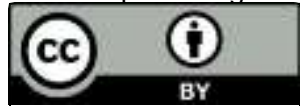

(c) SEAJME. This is an Open Access article distributed under the terms of the Creative Commons Attribution License (http://creativecommons.org/licenses/by/4.0/), which permits unrestricted use, distribution, and reproduction in any medium, provided the original author and source are credited 


\section{Components of Teacher portfolio}

hand-in-hand with the collection of evidence which infers about the quality of teaching (Little-
Wienert \& Mazzigotti, 2018). Moreover, it is a good practice to solicit for testimonials from your peers, mentors or supervisors who are

\section{Table 1: Step-by-step guide for maintaining Teachers' Portfolio}

\begin{tabular}{|c|c|}
\hline Sr. No. & Parameters / Components \\
\hline 1 & Start the process early and periodically update the curriculum vitae \\
\hline 2 & Document your educational philosophy, goals \& objectives set for the education \\
\hline 3 & Solicit for testimonials from your peers, mentors or supervisors \\
\hline 4 & $\begin{array}{l}\text { Incorporate teaching details about the types of courses taught, teaching-learning methods, awards, } \\
\text { invited lectures, etc., }\end{array}$ \\
\hline 5 & $\begin{array}{l}\text { Clinical attributes: Includes clinical leadership roles, credits for academic programs, evaluation by the } \\
\text { head of the department or other stakeholders, clinical teaching, etc. }\end{array}$ \\
\hline 6 & $\begin{array}{l}\text { Administrative attributes: Encompasses the details about involvement in curriculum committee, member } \\
\text { of a dissertation committee, administrative positions held, mentor responsibilities, office-bearer in } \\
\text { academic societies, etc. }\end{array}$ \\
\hline 7 & $\begin{array}{l}\text { Add particulars about the role in the development of a curriculum, curricular innovations or revision, } \\
\text { education material, research articles in the field of medical education }\end{array}$ \\
\hline 8 & $\begin{array}{l}\text { Add other recognitions like Editorial Board Member, peer-reviewer, poster or podium presentation, } \\
\text { grants, organization of a workshop, examiner for peers, etc. }\end{array}$ \\
\hline 9 & Collect evidence about the quality of teaching \\
\hline 10 & $\begin{array}{l}\text { Document the areas in which professional growth is required and the plan which you have to attain the } \\
\text { growth }\end{array}$ \\
\hline
\end{tabular}

aware about your work and educational contribution. In addition, emphasis should be given towards writing down the educational philosophy, and the goals \& objectives set for the education (Sidhu, 2015, Little-Wienert \& Mazzigotti, 2018, Vallina Pérez, 2008). Further, evidence pertaining to the scholarship of teaching-learning should also be incorporated in the teaching portfolio. In general, with regard to teaching details about the types of courses taught, teaching-learning methods, awards, invited lectures, etc., can be recorded (Vallina Pérez, 2008).

For documenting the clinical attributes, the details about clinical leadership roles, credits for academic programs, evaluation by the head of the department or other stakeholders, clinical teaching, etc., can be added. From the administrative perspective, a teaching portfolio can include the details about involvement in curriculum committee, member of a dissertation committee, administrative positions held, mentor responsibilities, office-bearer in academic societies can be incorporated (Lamki \& Marchand, 2006, Sidhu, 2015). Finally, for the development of education, details about the role in the development of a curriculum, curricular innovations or revision, education material (viz. book chapters, patient education materials, web-based teaching materials, etc.), research articles in the field of medical education (Little-Wienert \& Mazzigotti, 2018, Vallina Pérez, 2008).

The teaching portfolio can be further strengthened by the addition of details pertaining to serving as an Editorial Board Member, peer-reviewer, poster or podium presentation, grants, organization of a workshop, and involvement as an examiner for peers (Sidhu, 2015, Vallina Pérez, 2008). It is also a good practice to document about the areas in which professional growth is required and the plan which you have to attain the growth. Eventually, it is a must that all the things which are documented in teaching portfolio are supported with evidences (like certificates, research articles, letter of invitation, editorial board or peer reviewer member, photographs, educational material, etc.) for the same (Sidhu, 2015, Little-Wienert \& Mazzigotti, 2018, Vallina Pérez, 2008).

\section{Conclusion}

In conclusion, the practice of maintaining a teaching portfolio should be encouraged by all the medical colleges as this is bound to affect the professional growth of teachers, impact students' learning and also enhance the level of satisfaction while serving as a teacher in a medical college. 


\section{References}

Lamki. N. \& Marchand, M. (2006) The medical educator teaching portfolio: its compilation and potential utility. Sultan Qaboos Univ Med J. 6, 1, pp. 7-12.

Little-Wienert, K. \& Mazziotti, M. (2018) Twelve tips for creating an academic teaching portfolio. Med Teach 40, 1, pp. 26-30.
Sidhu, N.S. (2015) The teaching portfolio as a professional development tool for anaesthetists. Anaesth Intensive Care 43, 3, pp. 328-334.

Vallina Pérez, J.L. (2008) Teaching portfolio. Much more than the sum of the parts. Aten Primaria 40, 8, pp. 425. 